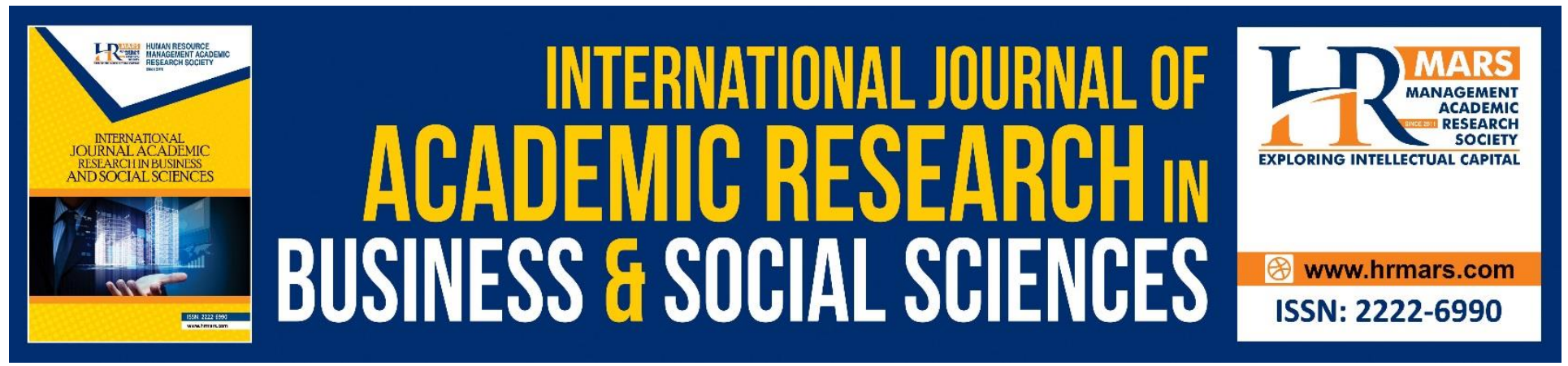

\title{
The Effect of Distress and Social Support on Workplace Incivility and Turnover Intention among Malaysian Casual Dining Restaurant Employees: A Proposed Framework
}

Saedahtinnur Hashim, Hazrina Ghazali, Siti Fatimah Mohamad, Roziah Mohd Rasdi and Mohhidin Othman

To Link this Article: http://dx.doi.org/10.6007/IJARBSS/v9-i6/6071

DOI: $10.6007 /$ IJARBSS/v9-i6/6071

Received: 17 April 2019, Revised: 17 May 2019, Accepted: 07 June 2019

Published Online: 27 June 2019

In-Text Citation: (Hashim, Ghazali, Mohamad, Rasdi, \& Othman, 2019)

To Cite this Article: Hashim, S., Ghazali, H., Mohamad, S. F., Rasdi, R. M., \& Othman, M. (2019). The Effect of Distress and Social Support on Workplace Incivility and Turnover Intention among Malaysian Casual Dining Restaurant Employees: A Proposed Framework. International Journal of Academic Research in Business and Social Sciences, 9(6),1094-1103.

Copyright: (c) 2019 The Author(s)

Published by Human Resource Management Academic Research Society (www.hrmars.com)

This article is published under the Creative Commons Attribution (CC BY 4.0) license. Anyone may reproduce, distribute, translate and create derivative works of this article (for both commercial and non-commercial purposes), subject to full attribution to the original publication and authors. The full terms of this license may be seen at: http://creativecommons.org/licences/by/4.0/legalcode

Vol. 9, No. 6, 2019, Pg. $1094-1103$

Full Terms \& Conditions of access and use can be found at http://hrmars.com/index.php/pages/detail/publication-ethics 


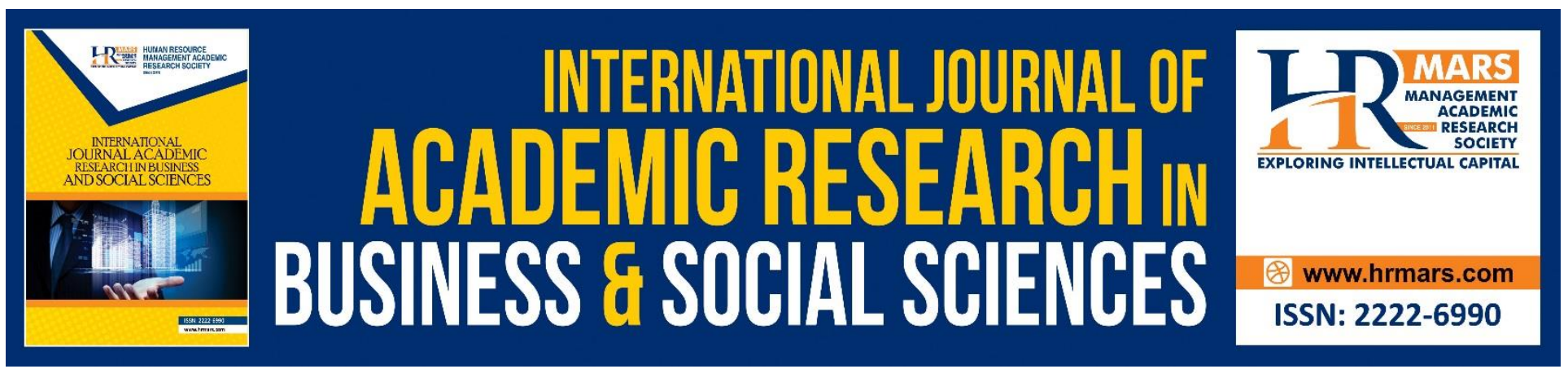

\title{
The Effect of Distress and Social Support on Workplace Incivility and Turnover Intention among Malaysian Casual Dining Restaurant Employees: A Proposed Framework
}

\author{
Saedahtinnur Hashim ${ }^{1,2^{*}}$, Hazrina Ghazali², Siti Fatimah Mohamad², \\ Roziah Mohd Rasdi ${ }^{3}$, and Mohhidin Othman ${ }^{2}$ \\ ${ }^{1}$ Department of Family and Consumer Science, Faculty of Technical and Vocational, Universiti \\ Pendidikan Sultan Idris, 35900 Tanjung Malim, Perak, Malaysia \\ ${ }^{2}$ Department of Food Service and Management, Faculty of Food Science and Technology, Universiti \\ Putra Malaysia, 43400 UPM Serdang, Selangor, Malaysia \\ ${ }^{3}$ Department of Professional Development and Continuing Education, Faculty of Educational Studies \\ Universiti Putra Malaysia, 43400 UPM Serdang, Selangor, Malaysia
}

\begin{abstract}
Employee's turnover intention that is related to organisational behaviour has been a serious concern in many organisations. Negative workplace behaviour is known as "workplace incivility" has shown strong relation to the adverse outcomes such as intention to quit or emotional exhaustion. Even though the vital incivility role in employee's working life is realized, research on moderators and mediators in the relationship between workplace incivility and organisational outcome are scarce. Therefore, this study will examine the mediation effect of distress and the moderating effect of workplace social support on the relationship between incivility and employee's turnover intention by adapted Job-Resource Demand (JD-R) model. A quantitative research approach using a selfcompletion questionnaire will be distributed to employees who are working in the casual dining restaurant in the Central region of Malaysia. This study will employ non-probability sampling, and more than 800 employees are expected to participate. The analysis of the data will use Structural Equation Modeling (SEM) using AMOS. The findings of this study expected will help food service organisation to pinpoint the types and patterns of unusual behaviour in the workplace and contemplate how their employee respond to workplace incivility. Therefore better strategies can be formulated to minimise turnover intention among employees.
\end{abstract}

Keywords: Workplace Incivility, Distress, Social Support, Turnover Intention, Casual Dining Restaurant 
INTERNATIONAL JOURNAL OF ACADEMIC RESEARCH IN BUSINESS AND SOCIAL SCIENCES

Vol. 9, No. 6, June, 2019, E-ISSN: 2222-6990 @ 2019 HRMARS

\section{Introduction}

Aon Hewitt's Survey in South East Asia revealed that Malaysia was reported as the third highest employees' voluntary turnover rate at $9.5 \%$ and second highest involuntary turnover rate at $6.0 \%$ (Aon Hewitt's Study, 2015). The turnover rate among Malaysian restaurant employee also recorded as the second highest among other Asian countries in 2011. The result from Ghazali (2010) study found that within two years after employment, $70 \%$ of restaurant employees intend to quit their job. It is similar to the finding gain from Malaysia Insider (2014) which reported that $70 \%$ of workers in Malaysian food and beverage industry are considering leaving their job. There are many studies on turnover intentions in food service organizations that have been conducted in Malaysia. However, most studies focusing on the fast food industry (Ghazali, 2010; Ryan, Ghazali \& Mohsin, 2011). Research on the turnover intentions relating to organizational behavior is commonly focused on incidents such as deviance, violence, and bullying and workplace aggression within education, manufacturing, retail, public services or government, hospitals and healthcare services industries (Bennett \& Robinson 2000; Ashraf \& Khan, 2014; Bunk \& Magley, 2013). A newer extension for this research has resulted in a negative workplace behaviour that now represents the term "workplace incivility" (Walker, Van Jaarsyeld \& Skarlicki, 2014). However, research on turnover intentions associated with organizational behavior such as workplace incivility in the restaurant industry is still limited in both Western and Asian countries.

Workplace incivility includes the types of workplace mistreatment and daily hassles (Andersson \& Pearson, 1999; Cortina, Magley, Williams \& Langhout, 2001) such as demeaning or derogatory remarks, condescension, ignoring a co-worker and showing little interest in an employee's opinion. According to Lim, Cortina \& Magley (2009), workplace incivility considered as a critical job stressor because chronic uncivil events that happen frequently will affect employee's emotional and mental health and lead to psychological harm. Incivilities in the workplace continue to receive increasing attention as it often happens at work (Wilson \& Holmvall, 2013), but the scholarly hospitality literature related with incivility among service employee is surprisingly lacking (Han, Bonn \& Cho, 2016). Furthermore, recent research on workplace incivility and turnover focuses on strain such as burnout (Laschinger, Leiter, Day \& Gilin, 2009; Han et al., 2016); emotional exhaustion (Cortina et.al, 2001) and job stress (Mahfooz, Arshad, Nisar, Ikram \& Azeem, 2017), yet little attention has been paid to the distress as a mediating variable between this relationship. Also, the moderators that mitigated the relationship between workplace incivilities on distress should be considered. The moderators such as personal resources and organisational resources that buffer these adverse effects should be anticipated (Sakurai \& Jex, 2012; Zhang, Kwan, Zhang \& Wu, 2014).

Therefore this study aims to find out whether, 1) job strain such as distress will mediate the relationship between workplace incivility and turnover intention, 2) job resources such as social support moderate the relationship between workplace incivility and psychological distress. Based on Job Demand-Resource Model (Bakker \& Demerouti, 2007), this study will extend the scope of the turnover literature and incivility in the workplace and by adding the mediating variable like distress and social support as a moderating variable. The association of these variables with workplace 
INTERNATIONAL JOURNAL OF ACADEMIC RESEARCH IN BUSINESS AND SOCIAL SCIENCES

Vol. 9, No. 6, June, 2019, E-ISSN: 2222-6990 @ 2019 HRMARS

incivility and employee's turnover intention is the new contribution to the existing body of knowledge in general and in the context of Malaysia restaurant in particular.

\section{Literature Review}

The JD-R theory and model (Demerouti, Bakker, Nachreiner \& Schaufeli, 2001; Bakker \& Demerouti, 2007; Demerouti \& Bakker, 2014) has been used by previous studies to provide theoretical support in predicting employee turnover, organizational commitment, work enjoyment, job burnout, job performance and engagement a (Bakker, Demerouti \& Euwerna, 2005; Bakker, VanEmmerick \& Vanriet 2008; Bakke, Hakanen, Demerouti \& Xanthopoulou, 2007; Demerouti et al., 2001; Hakanen, Bakker and Schaufeli, 2006). There are two basic assumptions in the Job Demands-Resources (JD-R) model (Demerouti et al., 2001). The job resource demand (JD-R) model assumes that "each occupation is associated with a unique pattern of job stress, and these stresses assume two basic forms: job demands and job resources" (Bakker \& Demerouti, 2014). According to Bakker and Demerouti ( 2007), job demands refer to those "physical, social, or organisational aspects of the job that involve constant physical and/or psychological (cognitive and emotional) effort or skills and are associated with certain physiological and/or psychological costs". An unfavourable workplace environment, high work pressure, and emotionally demanding interactions with the customer and are an example of job demands. Job resources refer to "those physical, psychological, social, or organisational aspects of the job that are either/or reduce job demands and the related psychological and physiological and costs; stimulate personal growth, learning, and development and functional in achieving work goals" (Bakker \& Demerouti, 2007). Job resources may found at a level of organisation or task, the organisation of work and the interpersonal and social relations such as co-worker and supervisor support, team climate, task identity and career opportunities (Hobfoll, 2001).

\section{Workplace Incivility and Turnover Intention}

Turnover intention is defined as "the behavioral attitude of a person desiring to withdraw or quit from their current job or an organization" (Aydogdu \& Asikgil, 2011), and has been determined to be an effective predictor of actual turnover (Hom \& Griffeth 1991; Rahman, Naqvi, \& Ramay 2008; Vardaman, Allen, Taylor \& Gondo, 2012). The decision of an employee to leave the organisation will highly cost to individual and organisation (Lee et al., 2004). When exposed to uncivil acts, victims may have difficulty making sense of and controlling the situation. Anxiety, distress, and resignation may arise and, eventually, in an attempt to avoid the source of stress, targets of incivility may decide to leave the organisation (Sguera, Bagozzi, \& Boss, 2011). Empirical evidence lends support to this argument. The result from Pearson, Anderson and Porath (2000) study showed that employees who experienced incivility at the workplace considered leaving their jobs. Similarly, Cortina et al. (2001) and Lim, Cortina \& Magley (2008) found that uncivil experiences were associated with turnover intentions. Past research also found that work incivility has a negative relationship with job satisfaction and productivity but has a positive relationship with absenteeism, lateness and turnover intention (Lim \& Cortina, 2005; Penney \& Spector, 2005; Rahim \& Cosby, 2015). In other word, incivilities lead to the intention of resignation (Rahim \& Cosby, 2015). Based on the discussion above, this study hypothesised the following: 
INTERNATIONAL JOURNAL OF ACADEMIC RESEARCH IN BUSINESS AND SOCIAL SCIENCES Vol. 9, No. 6, June, 2019, E-ISSN: 2222-6990 @ 2019 HRMARS

H1: There is a significant relationship between workplace incivility and employee's turnover intention.

\section{Mediating Role of Distress}

Psychological distress is defined as "a state of emotional suffering, characterised by symptoms of anxiety (i.e., feeling tense, nervousness) and depression (i.e., sadness, hopelessness)", (Drapeau, Marchand \& Beaulieu-Prevost, 2012). There is empirical evidence supporting the mediating role of others type of strain such as emotional exhaustion and burnout on the relationship between stressors and outcomes. A study done by previous research revealed that psychological strain such as emotional exhaustion (Cortina et al., 2001; Shahryyari \& Ahmad, 2017), burnout (Laschinger, et.al, 2009; Han, et.al, 2016; Rahim \& Cosby, 2016) and job stress (Mahfooz et.al 2017) mediated the relationship between workplace incivility and employee's turnover intention. Yavas, Babakus \& Karatepe (2008) in their study among frontline hotel employees in Turkey found the relationship between family-work conflict and turnover intentions was influenced by emotional exhaustion. Furthermore, result from a study done by Karatepe and Aleshinloye's (2009) showed that the relationship between emotional dissonance and turnover intentions among frontline employees in a Nigerian hotel was partially mediated by emotional exhaustion. Babakus, Yavas, and Ashill (2009) study also revealed that the relationship between job demands on turnover partially mediated by burnout. In addition, the energetic pathway of the JD-R model emphasised that job demand (workplace incivility) may lead to a negative organisational outcome (turnover intention) through strain (distress). Therefore, based on the JD-R model and finding from previous research that uses another type of psychological strain as mediating variable, it is proposed that distress relationship between workplace incivility and turnover intention among the employee of casual dining restaurant.

\section{H2. Distress will significantly mediate the relationship between workplace incivility and turnover intention.}

\section{Moderating Roles of Social Support}

Social support refers to "an interpersonal transaction that involves emotional concern, instrumental aid, information, or appraisal" (Carlson \& Perrewé, 1999). It is also defined as the help or care from others person that individual can accept, feel or notice (Wang, Cai, Qian \& Peng, 2014). Good social support can help in maintaining a good emotional experience and protect an individual who is under stress (Maulik, Eaton \& Bradshaw, 2011). Previous research on work pressure done by Cohen and Wills (1985) emphasizes that social support can play a vital role in a workplace pressure environment. The researchers highlight that employee may be less affected by stressful workplace event if they feel organizationally supported. Supported by Perrot, Bauer, Abonneau, Campoy, Erdogan and Liden (2014), an individual who feels been cared and given support from whom they interact socially, more likely to less affected and less damaged from those who unable to cope with a workplace pressure situation. The later study by Hur, Moon and Jun (2013) has emphasised the importance of employees' perceptions about their organisational support to ensure the success of business operations and how organisational support may influence workers, who often feel in stressful condition. Thus, this study proposed the following hypothesis: 
INTERNATIONAL JOURNAL OF ACADEMIC RESEARCH IN BUSINESS AND SOCIAL SCIENCES Vol. 9, No. 6, June, 2019, E-ISSN: 2222-6990 @ 2019 HRMARS

H3. Social support will significantly moderate the relationships between workplace incivility and distress.

\section{Proposed Conceptual Framework}

Based on the previous literature, this paper proposes that workplace incivility and employee's turnover intention have a positive relationship. Moreover, it is also proposed that distress will mediate the relationship between incivility in the workplace and turnover intention. Additionally, past literature also found that social support act as an important factor to buffer the relationship between workplace incivility and strain. So it is proposed that the relationship between workplace incivility and distress is moderated by the social support organisational. The overall proposed framework is shown in figure 1.

Independent Variable

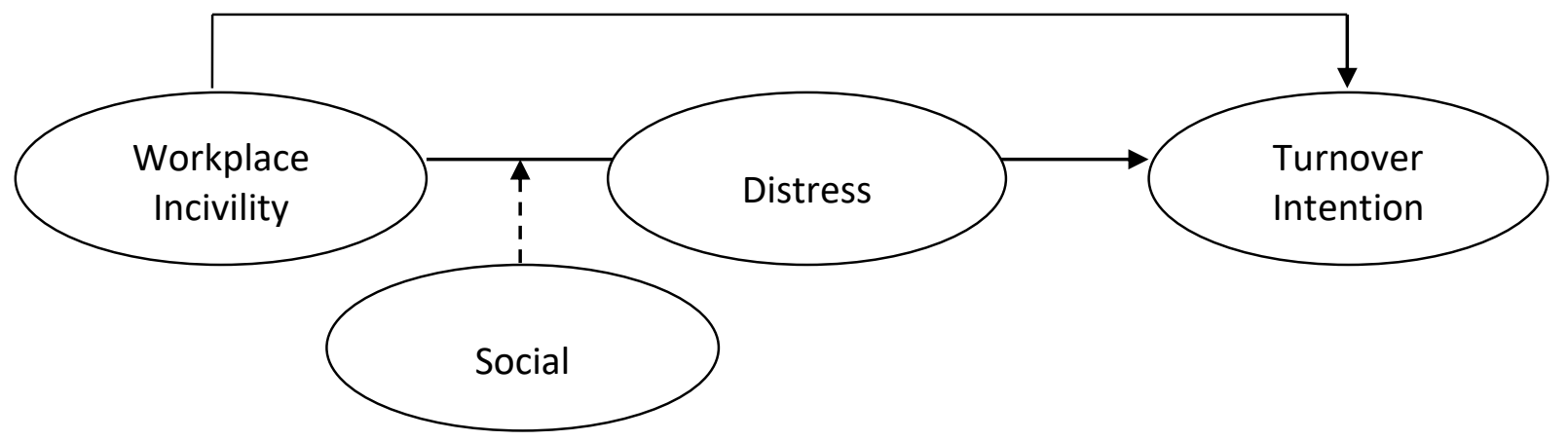

Mediating Variable

\section{Dependent Variable}

\section{Moderating Variable}

Figure 1: A proposed Conceptual Framework.

\section{Methodology}

A quantitative research approach with a cross-sectional survey design using a self-completion questionnaire will be distributed to casual dining restaurant employees who are working in the Central region of Malaysia. Items in the questionnaire will be adapted and modified from previous studies to fit the research context. Section A consists of workplace incivility construct adapted from Martin \& Hine (2005) and Wilson \& Holmvail (2013). Section B consists of distress construct adapted from Kessler, Andrews, Colpe, Hiripi, Mroczek, Normand, Walters, and Zaslavsky (2002). Section C consists of the moderating variable construct which is social support adapted from Karasek, Brisson, Kawakami, Houtman and Bongers (1998) and Eisenberger, Hungtington Hutchison and Sowa (1986). Section D consists of dependent variable items which are the turnover intention. This construct will be measured using a 6-item developed by Roodt (2009). All items in this section will be evaluated on a five-point response scale (1=Strongly Disagree, 5=Strongly Agree). 
The population of the study comprises of casual dining restaurants that are operating in the Central region of Malaysia which is Selangor, Wilayah Persekutuan and Negeri Sembilan. The sample frame will be a frontline employee of casual dining restaurant. The sample size will be determined by considering the number of the respondent suitable for factor analysis and structural equations modelling (SEM). Nunnally, 1978 suggest at least a 10 to 1 ratio; that is ten cases for each item to be factor analysed and Ho, 2006 recommend the minimum ratio of 10: 1 for SEM analysis. By using the recommendation, the minimum total respondents that valid for this study is $n=790$ (10 79 items). This study will employ non-probability sampling, and it is expected that more than 800 employees will participate. The data will be analysed using computer software called the SPSS version 24.0 for Windows. The researcher will use a descriptive statistic to measure the level of the all variable which is the turnover intention, workplace incivility, distress and social support. Finally, the researcher will run SEM to test the hypothesis and verify the proposed research model.

\section{Conclusion}

As depicted in Figure 1, this paper has proposed the relationship between workplace incivility and employee's turnover intention will be mediated by distress and the relationship between workplace incivility and distress will be moderated by workplace social support. The finding of this study will provide important awareness to restaurant management about how workplace incivility experienced by an employee in the workplace will lead to turnovers intention through distress and how social support plays a role in the buffer the adverse effect of workplace incivility on distress.

\section{Corresponding Author}

Saedahtinnur Hashim

Department of Food Service and Management, Faculty of Food Science and Technology,

Universiti Putra Malaysia, 43400 UPM Serdang,

Selangor, Malaysia

Email: saedahtinnur@gmail.com

\section{References}

Andersson, L. \& Pearson, C. (1999). Tit for tat? The spiralling effect of incivility in the workplace. Academy of Management Review, 24(3): 452-471.

Aon Hewitt (2015). 2015 Trends in Global Employee Engagement, Lincolnshire, IL.

Ashraf, F. and Khan, M.A. (2014), "Does emotional intelligence moderate the relationship between workplace bullying and job performance \& quest", Asian Business \& Management, Vol. 13 No. 2, pp. 171-190.

Aydogdu, S., \& Asikgil, B. (2011). An empirical study of the relationship among job satisfaction, organizational commitment and turnover intention. International review of management and marketing, 1(3), 43-53.

Bakker, A. B., \& Demerouti, E. (2007). The job demands-resources model: State of the art. Journal of Managerial Psychology, 22, 309-328. doi:10.1108/02683940710733115. 
INTERNATIONAL JOURNAL OF ACADEMIC RESEARCH IN BUSINESS AND SOCIAL SCIENCES

Vol. 9, No. 6, June, 2019, E-ISSN: 2222-6990 @ 2019 HRMARS

Bakker, A. B., and Demerouti, E. (2014), "Job demands-resources theory", in Chen, P.Y. and Cooper, C.L. (Eds), Work and Wellbeing: Wellbeing: A Complete Reference Guide, John Wiley \& Sons, Vol. 3.

Bakker, A. B., Demerouti, E. and Euwema, M. C. (2005). "Job resources buffer the impact of job demands on burnout", Journal of Occupational Health Psychology, Vol. 10 No. 2, pp. 170-180.

Bakker, A. B., Hakanen, J. J., Demerouti, E. and Xanthopoulou, D. (2007). “Job resources boost work engagement, particularly when job demands are high", Journal of Educational Psychology, Vol. 99 No. 2, pp. 274-284.

Bakker, A. B., VanEmmerik, H. and VanRiet, P. (2008), “How job demands, resources, and burnout predict objective performance: a constructive replication", Anxiety, Stress and Coping, Vol. 21 No. 9, pp. 309-324.

Babakus, E., Yavas, U., \& Ashill, N. J. (2009). The role of customer orientation as a moderator of the job demand burnout-performance relationship: A surface-level trait perspective. Journal of Retailing, 85(4), 480-492.

Bennett, R. J. and Robinson, S. L. (2000). "Development of a measure of workplace deviance”, Journal of Applied Psychology, Vol. 85 No. 3, pp. 349-360.

Bothma, C. F., \& Roodt, G. (2013). The validation of the turnover intention scale. SA Journal of Human Resource Management, 11(1), 1-12.

Bunk, J. A. and Magley, V. J. (2013), "The role of appraisals and emotions in understanding experiences of workplace incivility", Journal of Occupational Health Psychology, Vol. 18 No. 1, pp. 87-105.

Carlson, D. S., \& Perrewe, P. L. (1999). The role of social support in the stressor-strain relationship: An examination of work-family conflict. Journal of management, 25(4), 513-540.

Cohen, S. and Wills, T. A. (1985), "Stress, social support, and the buffering hypothesis", Psychological Bulletin, Vol. 98 No. 2, pp. 310-357.

Cortina, L. M. \& Magley, V. J. (2009). Patterns and profiles of response to incivility in the workplace. Journal of Occupational Health Psychology, 14(3): 272-288.

Cortina, L. M., Magley, V. J., Williams, J. H. and Langhout, R. D. (2001), "Incivility in the workplace: incidence and impact". Journal of Occupational Health Psychology, Vol. 6 No. 1, pp. 64-80.

Demerouti, E., Bakker, A. B., Nachreiner, F. and Schaufeli, W. B. (2001), "The job demands resources model of burnout", Journal of Applied Psychology, Vol. 86, pp. 499-515.

Drapeau, A., Marchand, A., \& Beaulieu-Prevost, D. (2012). Epidemiology of psychological distress. In Mental illnesses-understanding, prediction and control. InTech.

Eisenberger, R., Cummings, J., Armeli, S. and Lynch, P. (1997), "Perceived organizational support, discretionary treatment, and job satisfaction", Journal of Applied Psychology, Vol. 82 No. 5, pp. 812-820.

Ghazali, H. (2010). Employee intention to leave a job: A case of Malaysian fast food industry. University of Waikato.

Han, S. J., Bonn, M. A., \& Cho, M. (2016). The relationship between customer incivility, restaurant frontline service employee burnout and turnover intention. International Journal of Hospitality Management, 52, 97-106.

Hakanen, J. J., Bakker, A. B. and Schaufeli, W. B. (2006), "Burnout and work engagement among 
INTERNATIONAL JOURNAL OF ACADEMIC RESEARCH IN BUSINESS AND SOCIAL SCIENCES

Vol. 9, No. 6, June, 2019, E-ISSN: 2222-6990 @ 2019 HRMARS

teachers", Journal of School Psychology, Vol. 43 No. 6, pp. 495-513.

Ho, R. (2006). Handbook of univariate and multivariate data analysis and interpretation with SPSS. Chapman and Hall/CRC.

Hobfoll, S. E. (2001). The influence of culture, community, and the nested-self in the stress process: Advancing conservation of resources theory. Applied Psychology: An International Review, 50, 337-421. doi:10.1111/ 1464-0597.00062

Hom, P. W. \& Griffeth, R. W. (1991). Structural Equations Modeling Test of a Turnover Theory: CrossSectional and Longitudinal Analyses. Journal of Applied Psychology, 76, 350-366.

Hur, W. M., Moon, W. T. and Jun, J. K. (2013), "The role of perceived organizational support on emotional labor in the airline industry", International Journal of Contemporary Hospitality Management, Vol. 25 No. 1, pp. 105-123

Karatepe, O. M., \& Aleshinloye, K. D. (2009). Emotional dissonance and emotional exhaustion among hotel employees in Nigeria. International Journal of Hospitality Management, 28(3), 349-358.

Kessler, R. C., Andrews, G., Colpe, L. J., Hiripi, E., Mroczek, D. K., Normand, S. L., Walters, E. E. and Zaslavsky, A. M., (2002). Short screening scales to monitor population prevalences and trends in non-specific psychological distress. Psychological medicine, 32(6), 959-976.

Karasek, R., Brisson, C., Kawakami, N., Houtman, I., Bongers, P., \& Amick, B. (1998). The Job Content Questionnaire (JCQ): an instrument for internationally comparative assessments of psychosocial job characteristics. Journal of occupational health psychology, 3(4), 322.

Laschinger, H. K., Leiter, M., Day, A. and Gilin, D. (2009), "Workplace empowerment, incivility, and burnout: impact on staff nurse recruitment and retention outcomes", Journal of Nursing Management, Vol. 17 No. 3, pp. 302-311.

Lee, M. C. M. A. B. S. J. H. K. H. (2016). Workplace Incivility and its Effect upon Restaurant Frontline Service Employee Emotions. International Journal of Contemporary Hospitality Management, 28(22). https://doi.org/10.1108/IJCHM-04-2015-0205

Lim, S., \& Cortina, L. M. (2005). Interpersonal mistreatment in the workplace: the interface and impact of general incivility and sexual harassment. Journal of applied psychology, 90(3), 483.

Lim, S., Cortina, L. M. and Magley, V. J. (2008), "Personal and workgroup incivility: impact on work and health outcomes", Journal of Applied Psychology, Vol. 93 No. 1, pp. 95-107

Martin, R. J., \& Hine, D. W. (2005). Development and validation of the uncivil workplace behavior questionnaire. Journal of occupational health psychology, 10(4), 477.

Mahfooz, Z., Arshad, A., Nisar, Q. A., Ikram, M., \& Azeem, M. (2017). Does Workplace Incivility \& Workplace Ostracism influence the Employees' Turnover Intentions? Mediating Role of Burnout and Job Stress \& Moderating Role of psychological Capital. International Journal of Academic Research in Business and Social Sciences, 7(8), 398-413.

Maulik, P. K., Eaton, W. W., \& Bradshaw, C. P. (2011). The effect of social networks and social support on mental health services use, following a life event, among the Baltimore Epidemiologic Catchment Area cohort. The journal of behavioral health services \& research, 38(1), 29-50.

Nunnally, J. C. (1978). Psychometric theory (2nd ed.). New York: McGraw-Hill

Pearson, C., Andersson, L., \& Porath, C. 2000. Assessing and Attacking Workplace Incivility Organizational dynamics, 29(2): 123-137.

Penney, L. M., \& Spector, P. E. (2005). Job stress, incivility, and counterproductive work behavior 
INTERNATIONAL JOURNAL OF ACADEMIC RESEARCH IN BUSINESS AND SOCIAL SCIENCES

Vol. 9, No. 6, June, 2019, E-ISSN: 2222-6990 @ 2019 HRMARS

(CWB): The moderating role of negative affectivity. Journal of organizational behavior, 26(7), 777-796.

Perrot, S., Bauer, T. N., Abonneau, D., Campoy, E., Erdogan, B. and Liden, R. C. (2014), “Organizational socialization tactics and newcomer adjustment the moderating role of perceived organizational support", Group \& Organization Management, Vol. 39 No. 3, pp. 247-273.

Rahim, A., \& Cosby, D. M. (2016). A model of workplace incivility, job burnout, turnover intentions, and job performance. Journal of Management Development, 35(10), 1255-1265.

Ryan, C., Ghazali, H., \& Mohsin, A. (2011). Determinants of intention to leave a non-managerial job in the fast-food industry of West Malaysia. International Journal of Contemporary Hospitality Management, 23(3), 344-360. https://doi.org/10.1108/09596111111122523

Sakurai, K. and Jex, S. M. (2012), "Coworker incivility and incivility targets' work effort and counterproductive work behaviors: the moderating role of supervisor social support", Journal of Occupational Health Psychology, Vol. 17 No. 2, pp. 150-161

Sguera, F., Bagozzi, R. P., \& Boss, W. (2011). Workplace incivility and turnover intentions: The efficacy of managerial interventions. In Academy of Management Proceedings (Vol. 2011, No. 1, pp. 16). Briarcliff Manor, NY 10510: Academy of Management.

Shahryari, Y., \& Ahmad, K. Z. (2017, December). The moderating impact of resilience on the relationship between workplace incivility and turnover intentions: a proposed study in Dubai retail SME's. In International Conference on Advances in Business, Management and Law (ICABML) (Vol. 1, No. 1, pp. 236-243).

Walker, D. D., van Jaarsveld, D. D. and Skarlicki, D. P. (2014), "Exploring the effects of individual customer incivility encounters on employee incivility: the moderating roles of entity (in) civility and negative affectivity", Journal of Applied Psychology, Vol. 99 No. 1, pp. 151-161.

Wang, X., Cai, L., Qian, J., \& Peng, J. (2014). Social support moderates stress effects on depression. International Journal of Mental Health Systems, 8(1), 41.

Wilson, N. L. and Holmvall, C. M. (2013), "The development and validation of the incivility from customers scale", Journal of Occupational Health Psychology, Vol. 18 No. 3, pp. 310-326.

Zhang, H., Kwan, H. K., Zhang, X. and Wu, L. Z. (2014), "High core self-evaluators maintain creativity: a motivational model of abusive supervision", Journal of Management, Vol. 40 No. 4, pp. 11511174. doi: 10.1177/ 0149206312460681 